\title{
Roman double-layered crucibles from Autun/France: a petrological and geochemical approach
}

\author{
Daniela König*, Vincent Serneels \\ Department of Geosciences, University of Fribourg, Chemin du Musée 6, CH-1700 Fribourg, Switzerland
}

\begin{abstract}
Eighteen double-layered crucible fragments found in an archaeological excavation site of the Lycée militaire (Autun/France), which dates to the Gallo-Roman period, were analysed with a series of classical mineralogical techniques in order to obtain knowledge about the raw materials of the individual layers. This work focuses on the usage of the crucibles as well as technical aspects of their production. The crucible fragments were studied by using petrographical (optical microscopy), elemental (SEM-EDS, EMPA, XRF-WDS) and mineralogical (XRD) techniques.

The two main layers of the crucibles are made of high refractory, kaolinite-based ceramic with graniterelated temper grains. The analytical and petrographical results show remarkable differences between these two layers. The outer one is dominated by a high content of vitrified mullite-bearing matrix and contains analcime which was formed during the burial stage. In contrast, the inner layer is characterised by a non-vitrified matrix with a high content of orthorhombic mullite, $\beta$-cristobalite and $\alpha$-quartz. An engobe is detectable in the majority of the fragments. The mineral composition allows an estimation of the firing temperatures, which have reached approximately 1200 up to $1400{ }^{\circ} \mathrm{C}$.
\end{abstract}

\section{Introduction}

Crucibles and moulds from archaeological excavations are tools indicating specific metalworking practices of a certain period and bearing a large amount of information concerning the local metalworking, i.e. metal composition, production routine, etc. (e.g. Nielen, 2006; Tite et al., 1985).

Former studies generally distinguish between three functional groups of metalworking crucibles, namely cementation, assaying and melting crucibles (e.g. Bayley and Rehren, 2007). Melting crucibles are the most common type and are known since the Late Neolithic (Bayley and Rehren, 2007). It was necessary to construct them small but strong in order to guarantee easy handling of such metal charged vessels. Accordingly, the volume was commonly limited typically to a maximum of one litre of liquid metal, but often much less, prior to the Industrial Revolution. Such an usage also requires a fabric which ensures mechanical stability at temperatures well above $1000{ }^{\circ} \mathrm{C}$ (Bayley, 1992; Bayley and Rehren, 2007).

Individual crucibles show different fabric and material characteristics according to their special function. Bayley and Rehren

\footnotetext{
* Corresponding author. Tel.: +41 (0)263008946; fax: +41 (0)263009742.

E-mail address: daniela.koenig@unifr.ch (D. König).
}

(2007) classify crucibles using three main attributes: firstly, features related to the crucible design (e.g. shape and size), secondly, the ceramic fabric including mineralogical and structural features and thirdly, the technical function. One milestone in the development of crucibles is the usage of refractory materials, mainly white-firing kaolinitic clays. These materials first arose in the Late Iron Age, became a major component of crucibles during the Roman period, but their complete technical potential was only developed during the medieval period (Bayley and Rehren, 2007; Freestone, 1989; Martinón-Torres et al., 2008; Rehren, 2003; Thornton and Rehren, 2009). A common type of Roman crucible is characterised by a double-layered wall structure. Some authors suggest an insulation function of the outer layer which can give off heat more equally, thus reducing the probability of a thermal shock (e.g. Bayley and Rehren, 2007).

This article is a petrological and geochemical approach to identify and classify the metalworking crucibles from Autun/ France. Individual aims are: (1) the detailed understanding of the ceramic structure and the investigation of the mineralogical/ geochemical composition of the two main layers; (2) the characterisation of a potential engobe with regard to function and characteristics; (3) the identification of multiple usages; (4) the calculation of mineral-related firing temperatures; (5) the understanding of the production processes of the crucibles. 


\section{Double-layered crucibles from Autun}

The modern town of Autun/France (Fig. 1) developed from the Roman town of Augustodunum, one of the most important settlements in Gaul. Excavations at the site of the Lycée militaire have brought to light a craftsman district dominated by copper-based metalworking. More than 50 workshops were producing between the 1 st and 3rd century A.D. (Chardron-Picault and Pernot, 1999).

Large quantities of crucible fragments $(650 \mathrm{~kg})$ and lids, and in few cases completely preserved crucibles (Fig. 2), were found in the area of the Lycée militaire. Preserved and reconstructed crucibles occur in slightly different shapes and at least three sizes with a volumetric capacity between 0.3 and $2.2 \mathrm{~L}$, i.e. $2.5-19 \mathrm{~kg}$ metallic charge. The crucible shapes are mainly cylindrical with a hemispherical base and some of them show a tapering shape to the top. Main types are reclosable with a separate lid and without any spout. This design is almost identical for all crucibles sizes.

\section{Analytical approach}

In order to have a representative selection of sample material, eighteen crucible fragments were selected from the excavation part US 1534 (see Chardron-Picault and Pernot, 1999). Fabric studies were made on polished thin-sections by using a polarising microscope and a "FEI SIRION XL 30S FEG" scanning electron microscope (SEM). Secondary electron (SE) and back-scattered images (BSE) were recorded with an acceleration potential of $20-25 \mathrm{kV}$, a beam current of $1.2 \mathrm{nA}$, a working distance of $8 \mathrm{~mm}$ and a measuring time of $50 \mathrm{~s}$ per point. Semi-quantitative chemical analyses were obtained by energy dispersive spectrometry (EDS) with an "EDAX NEW-XL30" detector. Cross-section scans were used to generate Xray maps of the elements $\mathrm{Al}, \mathrm{Na}, \mathrm{Mg}, \mathrm{Si}, \mathrm{P}, \mathrm{K}, \mathrm{Sn}, \mathrm{Ca}, \mathrm{Ti}, \mathrm{V}, \mathrm{Mn}, \mathrm{Fe}, \mathrm{Cu}$ and $\mathrm{Zn}(25 \mathrm{kV}-1.2 \mathrm{nA}$, dwell time $50 \mathrm{~ms}$ per pixel). The engobe were quantitatively analysed with a "JEOL JXA-8200" electron microprobe at the University of Bern ( $15 \mathrm{kV}-20 \mathrm{nA}, 5 \mu \mathrm{m}$ spot size).

Where possible, both main layers were manually separated and milled in a tungsten carbide pot using a vibratory disc mill. The total amount of sample material varied between 3 and $8 \mathrm{~g}$, depending on layer thickness and the size of the crucible fragment. X-ray diffraction (XRD) analyses were obtained from a "PHILIPS PW1800"

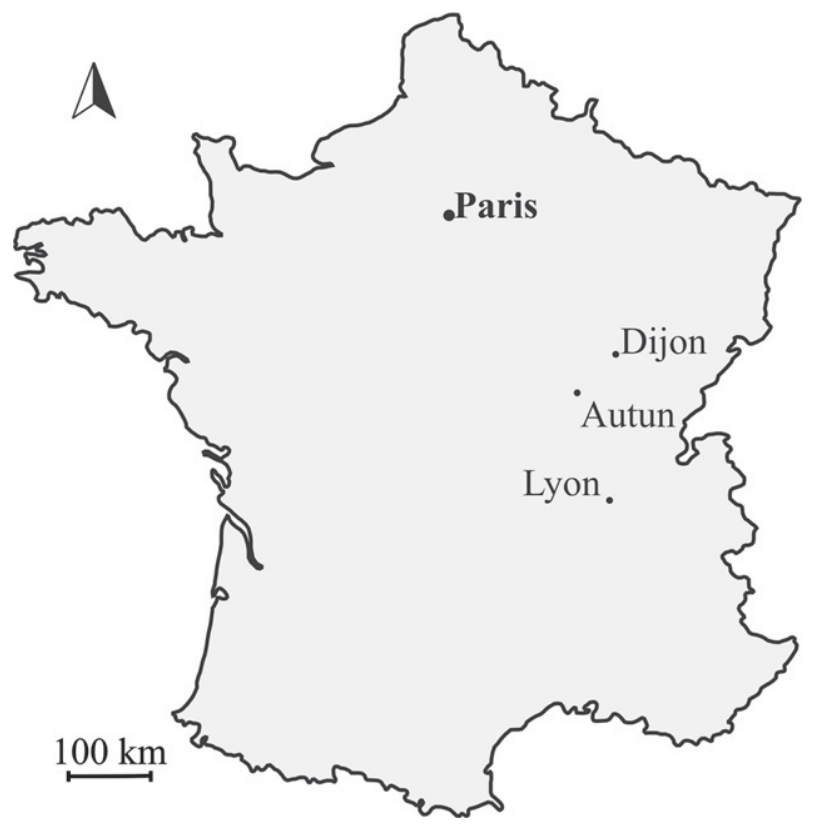

Fig. 1. Map of France with Autun in.
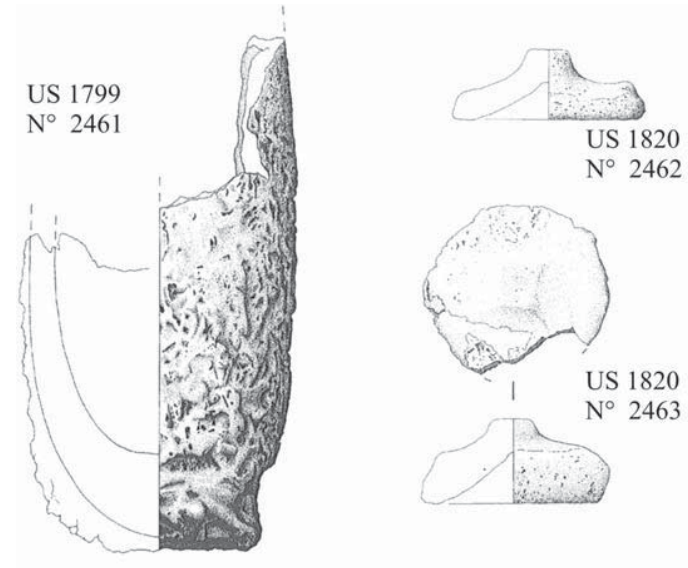

N 1820
$\mathrm{~N}^{\circ} 2462$
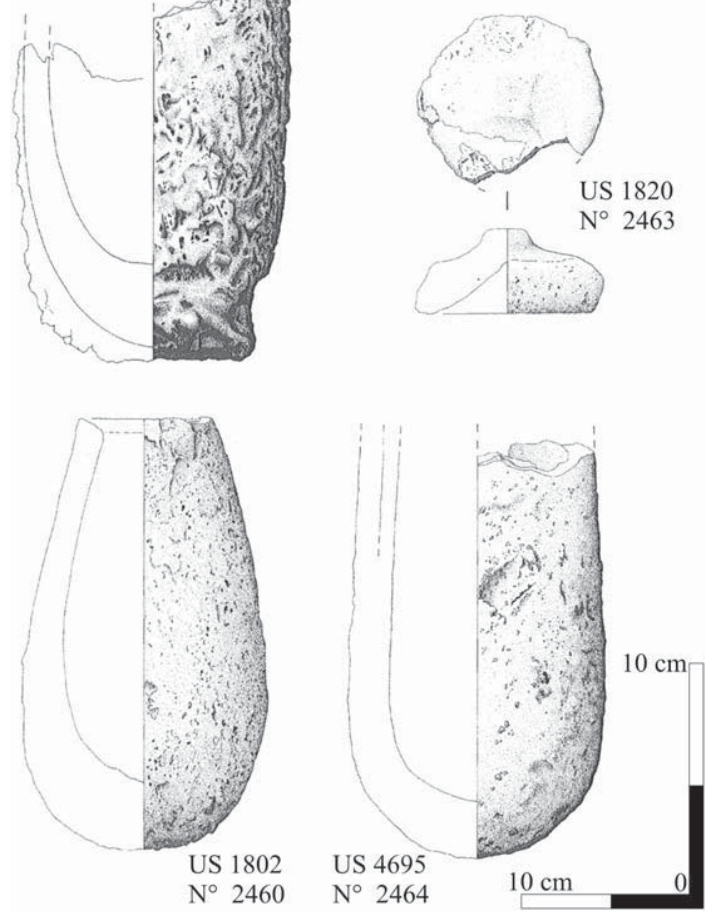

Fig. 2. Drawings of three representative crucible shapes from Autun; US 1799, N 2461 - inner diameter: $11.5 \mathrm{~cm}$, metal load: $21 \mathrm{~cm}$; US 1802, $\mathrm{N}^{\circ} 2460$ - inner diameter: $9.5 \mathrm{~cm}$, metal load: $18 \mathrm{~cm}$; US 4695, $\mathrm{N}^{\circ} 2464$ - inner diameter: $10.3 \mathrm{~cm}$, metal load: $18 \mathrm{~cm}$ (modified after Chardron-Picault and Pernot, 1999).

diffractometer with $\mathrm{CuK} \alpha$ radiation at $40 \mathrm{kV}-40 \mathrm{~mA}\left(0.02^{\circ} 2 \Theta /\right.$ step, $\left.5 \mathrm{~s} / \mathrm{step}, 5-90^{\circ} 2 \Theta\right)$. To determine the exact position of the (101)peak of cristobalite, a silicon standard was measured after each tenth sample.

Bulk chemical analyses were carried out with a "PHILIPS PW 2400" X-ray fluorescence wavelength dispersive spectrometer (XRF-WDS). All analyses were performed on pressed powder discs, which were prepared with $2.5-5 \mathrm{~g}$ of sample material and evaluated with the program "uniquant". The disc diameter is constant (32 mm), although thicknesses can vary as a function of the sample amount. Very thin discs were pressed twice with boric acid to guarantee definite stability during the measuring procedure. The loss on ignition (LOI) was estimated with the help of a "Mettler-Toledo TGA/SDTA 851e" thermogravimetry device (TGA). Raman spectroscopy was carried out on an "Olympus BX40" spectroscope (370 mW, $25 \mathrm{~A}$ ) equipped with a green laser.

\section{Results and discussion}

In general, all studied crucibles from Autun show a doublelayered wall structure as exemplarily shown in Fig. 3. Individual layers possess their own thicknesses and fabric characteristics. The thickness of the outer layer increases from top to bottom, while the inner one remains nearly constant (Table 1 ; Fig. 3). Outer and inner layers can optically be distinguished by their different colours and the vitrified/non-vitrified appearance. These optical features indicate mineralogical heterogeneities between single layers and individual fragments. The inner layer is covered by an added engobe (see Section 4.2) as already reported from other excavations 


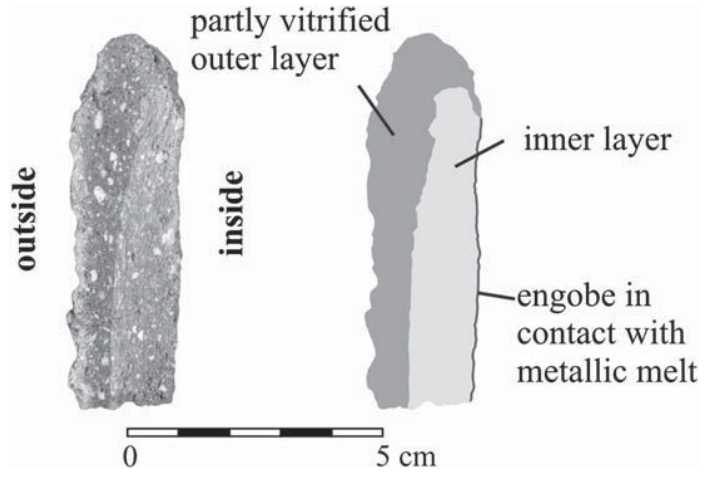

Fig. 3. Photograph of sample ATM 005 (left) and a sketch (right) of its main structural units.

like Neuss and Eberdingen-Hochdorf (Modarressi-Tehrani, 2004; Nielen, 2006). The outer, highly vitrified surface shows charcoal imprints implying heating from below. Copper-related colours (red and green) on the outer surface of the outer layer result from varying redox conditions during the metal-melting process in the furnace.

\subsection{Geochemical and mineralogical characterisation of the two main layers}

Macroscopically as well as microscopically it is possible to separate the layers with respect to their porosity, colour, grade of vitrification and the number and size of temper (Figs. 4 and 5). Observable matrix variations between both layers are linked to chemical and mineralogical variations. Temper grains consisting of quartz, feldspar and minor amounts of mica. Their proportions differ between the main layers of the investigated fragments. The outer layer consists of 60-70\% temper grains dominated by potassium feldspar over quartz. In contrast, the inner layer possesses a total of $40-50 \%$ temper grains with nearly equal amounts of potassium feldspar and quartz. Generally, temper grains are sharp edged and vary in size between tens of micrometres and some millimetres. The low amount of detectable mica flakes has no influence on thermal stability.

The outer layer shows a much higher porosity than the inner one, which is a direct consequence of its high degree of vitrification. During the firing process pore volume and size steadily increase until a maximum porosity is reached at a temperature around $950{ }^{\circ} \mathrm{C}-1050{ }^{\circ} \mathrm{C}$ (Maggetti and Kahr, 1980; May and Butterworth, 1962). A closed porosity within the glassy matrix is a common feature observed in all fragments of the outer layer. In contrast, the inner layer shows a semi-open porosity. These pores are a result of a thermally induced dehydroxylation and subsequent phase transformation of kaolinite to mullite during firing in the furnace and are not related to an addition of fibrous organic material.

SEM investigations show remarkable differences within the two main layers and the engobe, namely in texture (vitrified/nonvitrified). Moreover, calcium element maps and line measurements are suited to show major differences in bulk chemistry along the wall section. The border between the main layers as well as the engobe is marked by a significant change in the calcium content (Fig. 6). Moreover, the engobe is characterised by an appearance of metal droplets consisting of copper-tin or copper-zinc alloys (unpublished data). Additionally, element migration (Zn) related to the metal-melting process is observable along the inner layer. SEMBSE investigations are also suited to distinguish between primary mullite within the vitrified matrix and micrometre sized acicular secondary mullite in direct contact to potassium feldspar grains (Fig. 7) (Lee and Iqbal, 2001).

Based on XRD analyses (Table 1) quartz, mullite, potassium feldspar and cristobalite have been identified as the main constituents of both layers, accompanied by minor amounts of analcime in the outer layer. The amplitudes and the broadness of cristobalite peaks as well as a high background in the $40-55{ }^{\circ} 2 \Theta$ region indicate weak crystallinity and a high amount of glassy material within the outer layer of the ceramics. XRD detectable analcime is a typical alteration product of the vitrified phase developed in ceramics fired at high temperature (Pradell et al., 2010).

XRF bulk data verifies the chemical heterogeneities between both main layers. Table 2 summarises semi-quantitative data of the major components of the crucibles and indicates a dominance of $\mathrm{SiO}_{2}$ and $\mathrm{Al}_{2} \mathrm{O}_{3}$, followed by $\mathrm{K}_{2} \mathrm{O}$ in the inner and $\mathrm{CaO}$ in the outer layer, respectively. The content of alkali earth elements is mainly attributed to the matrix and the feldspar remnants therein. TG analyses yield a LOI of less than $0.2 \mathrm{wt}$.\% within the ceramics. This is the result of a relatively high firing temperature. However, LOI does not wholly account for the deviation of the total sum of the elements, which is in fact due to the utilisation of pressed powder discs, instead of more accurately measurable glass discs (Table 2).

The compositional variations of the main layers are also visible in diagrams of $\mathrm{Al}_{2} \mathrm{O}_{3}-\mathrm{SiO}_{2}, \mathrm{MgO}-\mathrm{SiO}_{2}, \mathrm{CaO}-\mathrm{SiO}_{2}$ and $\mathrm{K}_{2} \mathrm{O}-\mathrm{SiO}_{2}$,

Table 1

Crucible thickness and qualitative mineral content of both layers ( $\mathrm{i}$ - inner layer; o - outer layer) determined by XRD; some specimens could not be separated.

\begin{tabular}{|c|c|c|c|c|c|}
\hline Sample & Thickness (mm) bulk (in; out) & Existence of the engobe & $d_{101} \operatorname{Crs}(\mathrm{nm})$ & Mineral content - inner layer & Mineral content - outer layer \\
\hline ATM 001 & $19(12 ; 7)$ & $\mathrm{x}$ & 0.4062 & $\mathrm{Qtz}+\mathrm{Crs}+\mathrm{Mul}+\mathrm{Or}$ & $\mathrm{Qtz}+\mathrm{Crs}+\mathrm{Mul}+\mathrm{Anl}$ \\
\hline ATM 002 & $16(12 ; 4)$ & $\mathrm{x}$ & 0.4060 & $\mathrm{Qtz}+\mathrm{Crs}+\mathrm{Mul}+\mathrm{Or}$ & $\mathrm{Qtz}+\mathrm{Crs}+\mathrm{Mul}+\mathrm{Anl}$ \\
\hline ATM 003 & $16(6-12 ; 10-4)$ & $(\mathrm{x})$ & - & $\mathrm{Qtz}+\mathrm{Mul}+\mathrm{Lct}$ & $\mathrm{Qtz}+\mathrm{Mul}$ \\
\hline ATM 004 & $20(10 ; 10)$ & $\mathrm{x}$ & 0.4065 & $\mathrm{Qtz}+\mathrm{Mul}+\mathrm{Or}$ & $\mathrm{Qtz}+\mathrm{Crs}+\mathrm{Mul}$ \\
\hline ATM 005 & $21(8-12 ; 13-9)$ & $(\mathrm{x})$ & 0.4062 & $\mathrm{Qtz}+\mathrm{Crs}+\mathrm{Mul}$ & $\mathrm{Qtz}+\mathrm{Crs}+\mathrm{Mul}+\mathrm{Anl}+\mathrm{Spl}$ \\
\hline ATM 006 & $17(10 ; 7)$ & $\mathrm{x}$ & 0.4059 & $\mathrm{Qtz}+\mathrm{Crs}+\mathrm{Mul}+\mathrm{An}$ & $\mathrm{Qtz}+\mathrm{Crs}+\mathrm{Mul}+\mathrm{Anl}+\mathrm{An}$ \\
\hline ATM 007 & $15(9-12 ; 6-3)$ & $(\mathrm{x})$ & 0.4063 & $\mathrm{Qtz}+\mathrm{Crs}+\mathrm{Mul}+\mathrm{Lct}+\mathrm{Anl}$ & \\
\hline ATM 008 & $26-35(20-23 ; 15-3)$ & $\mathrm{x}$ & 0.4058 & $\mathrm{Qtz}+\mathrm{Crs}+\mathrm{Mul}+\mathrm{Or}$ & $\mathrm{Qtz}+\mathrm{Crs}+\mathrm{Mul}+\mathrm{Anl}$ \\
\hline ATM 009 & $37-69(22 ; 15-47)$ & $\mathrm{x}$ & 0.4061 & $\mathrm{Qtz}+\mathrm{Crs}+\mathrm{Mul}+\mathrm{Or}$ & $\mathrm{Qtz}+\mathrm{Crs}+\mathrm{Mul}$ \\
\hline ATM 010 & $40(21 ; 19)$ & & 0.4059 & $\mathrm{Qtz}+\mathrm{Crs}+\mathrm{Mul}$ & $\mathrm{Qtz}+\mathrm{Crs}+\mathrm{Mul}+\mathrm{Anl}+\mathrm{Or}$ \\
\hline ATM 011 & $45(20 ; 25)$ & & 0.4060 & $\mathrm{Qtz}+\mathrm{Crs}+\mathrm{Mul}+\mathrm{Or}$ & $\mathrm{Qtz}+\mathrm{Crs}+\mathrm{Mul}+\mathrm{Anl}+\mathrm{Or}$ \\
\hline ATM 012 & $16-20(11-12 ; 9-4)$ & $\mathrm{x}$ & 0.4059 & $\mathrm{Qtz}+\mathrm{Crs}+\mathrm{Mul}+\mathrm{Anl}$ & \\
\hline ATM 013 & $23(15 ; 8)$ & $\mathrm{x}$ & 0.4058 & $\mathrm{Qtz}+\mathrm{Crs}+\mathrm{Mul}$ & $\mathrm{Qtz}+\mathrm{Crs}+\mathrm{Mul}+\mathrm{Anl}$ \\
\hline ATM 014 & $22(18 ; 5)$ & $\mathrm{x}$ & 0.4058 & $\mathrm{Qtz}+\mathrm{Crs}+\mathrm{Mul}$ & $\mathrm{Qtz}+\mathrm{Crs}+\mathrm{Mul}+\mathrm{Anl}$ \\
\hline ATM 015 & $21-25(11-15 ; 10)$ & $\mathrm{x}$ & - & $\mathrm{Qtz}+\mathrm{Crs}+\mathrm{Mul}+\mathrm{Anl}$ & \\
\hline ATM 016 & $18(12-15 ; 6-3)$ & $\mathrm{x}$ & 0.4059 & $\mathrm{Qtz}+\mathrm{Crs}+\mathrm{Mul}+\mathrm{Or}$ & \\
\hline ATM 017 & $20-24(15-17 ; 5-7)$ & $\mathrm{x}$ & 0.4061 & $\mathrm{Qtz}+\mathrm{Crs}+\mathrm{Mul}$ & $\mathrm{Qtz}+\mathrm{Crs}+\mathrm{Mul}+\mathrm{Anl}+\mathrm{An}$ \\
\hline ATM 018 & $42(22 ; 20)$ & & - & $\mathrm{Qtz}+\mathrm{Mul}+$ Or & $\mathrm{Qtz}+\mathrm{Crs}+\mathrm{Mul}+\mathrm{Anl}$ \\
\hline
\end{tabular}

Mineral abbreviations: quartz (Qtz); cristobalite (Crs); mullite (Mul); analcime (Anl); orthoclase (Or); spinel (Spl); anorthite (An); leucite (Lct). 


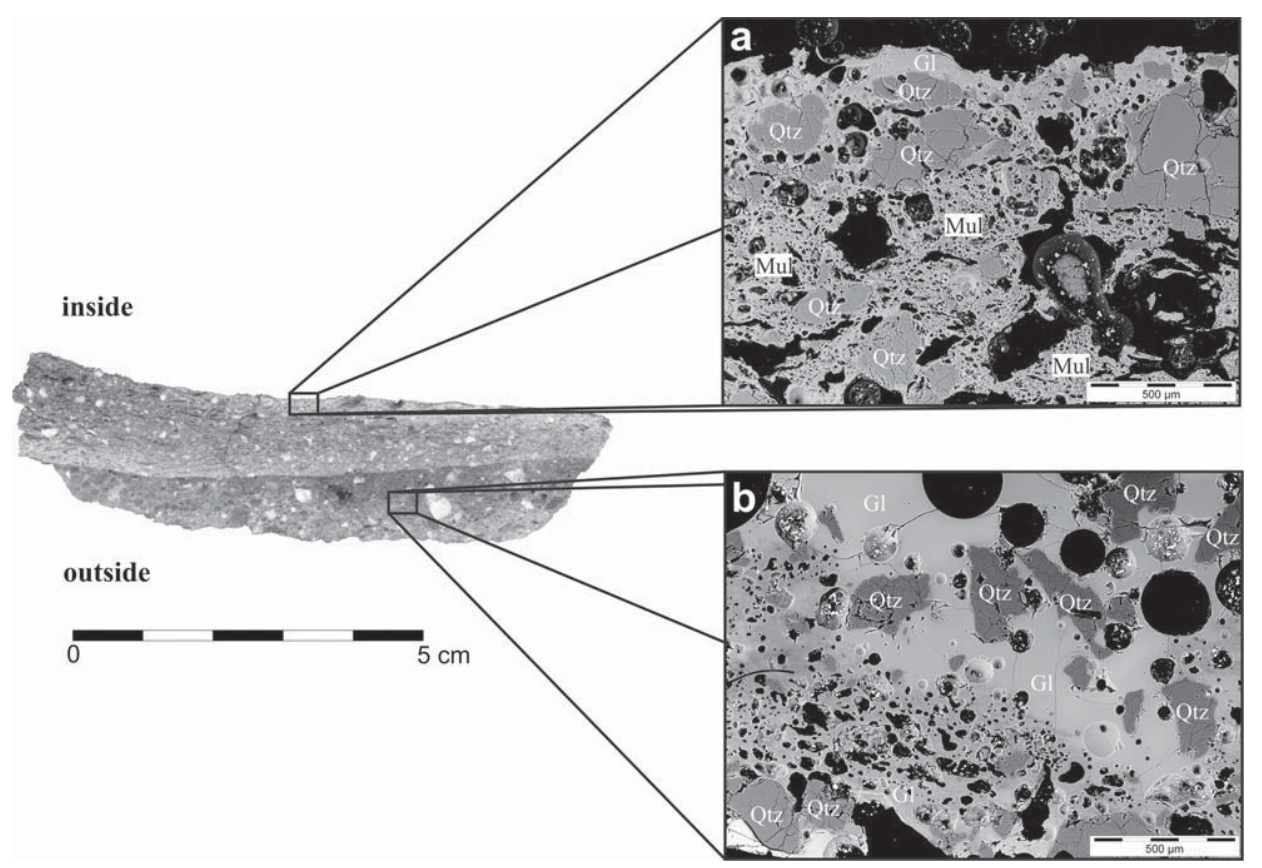

Fig. 4. Left: representative section through the crucible fragment ATM 004, which illustrates both main layers with different colour and fabric characteristics; right: SEM-BSE images representing the differing fabric characteristics of the inner (a) and outer (b) layer; Qtz - quartz; Mul - mullite; Gl - glass.

which allow a clear distinction (Fig. 8). The outer layer contains a higher amount of $\mathrm{CaO}, \mathrm{MgO}, \mathrm{K}_{2} \mathrm{O}$ and $\mathrm{Fe}_{2} \mathrm{O}_{3}$ tot than the inner one. The content of $\mathrm{Al}_{2} \mathrm{O}_{3}$ behaves contrariwise. The binary plots of $\mathrm{SiO}_{2} /$ $\mathrm{Al}_{2} \mathrm{O}_{3}-\mathrm{CaO}, \mathrm{SiO}_{2} / \mathrm{Al}_{2} \mathrm{O}_{3}-\mathrm{MgO}, \mathrm{Fe}_{2} \mathrm{O}_{3 \text { tot }} / \mathrm{Al}_{2} \mathrm{O}_{3}-\mathrm{CaO}$ and $\mathrm{Fe}_{2} \mathrm{O}_{3 \text { tot }} /$ $\mathrm{Al}_{2} \mathrm{O}_{3}-\mathrm{MgO}$ point toward two distinguishable clay types (Fig. 9).

i The above-mentioned results lead to a similar outcome and interpretation, namely that the inner and outer layers are different.
In general, it is possible to argue with two reasons for the present ceramic properties. Firstly, the differences in porosity and the total amount of vitrified matrix directly correspond to the chosen production routine. A second, but not less important cause is related to the kind of usage, i.e. the way the crucibles were used for the melt production, which had a direct impact on the observed zinc migration within the wall sections. The inner layer is made up
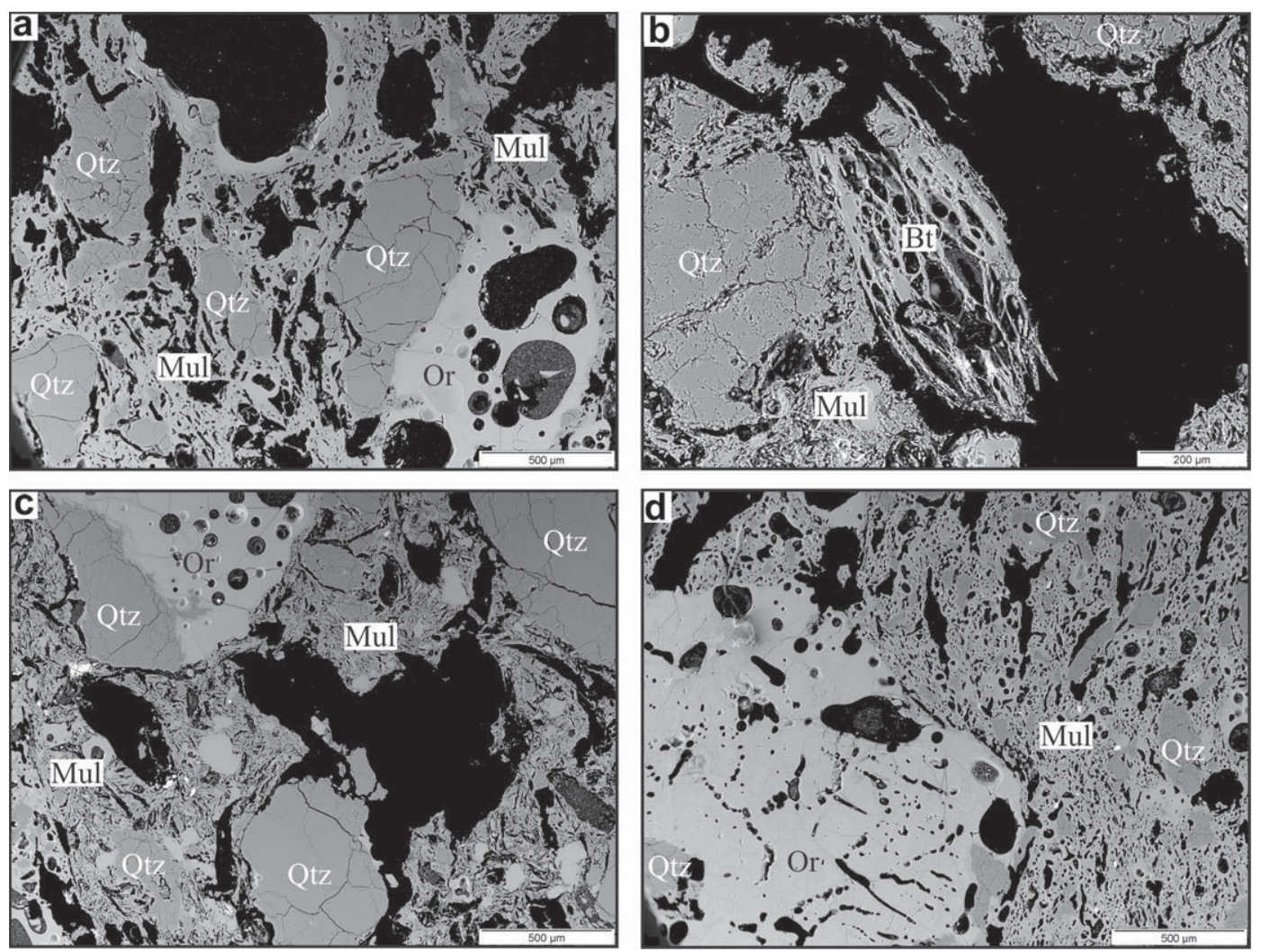

Fig. 5. (a-d) SEM-BSE images showing different types of temper grains within the inner layer; Qtz - quartz; Mul - mullite; Or - orthoclase; Bt - biotite. 

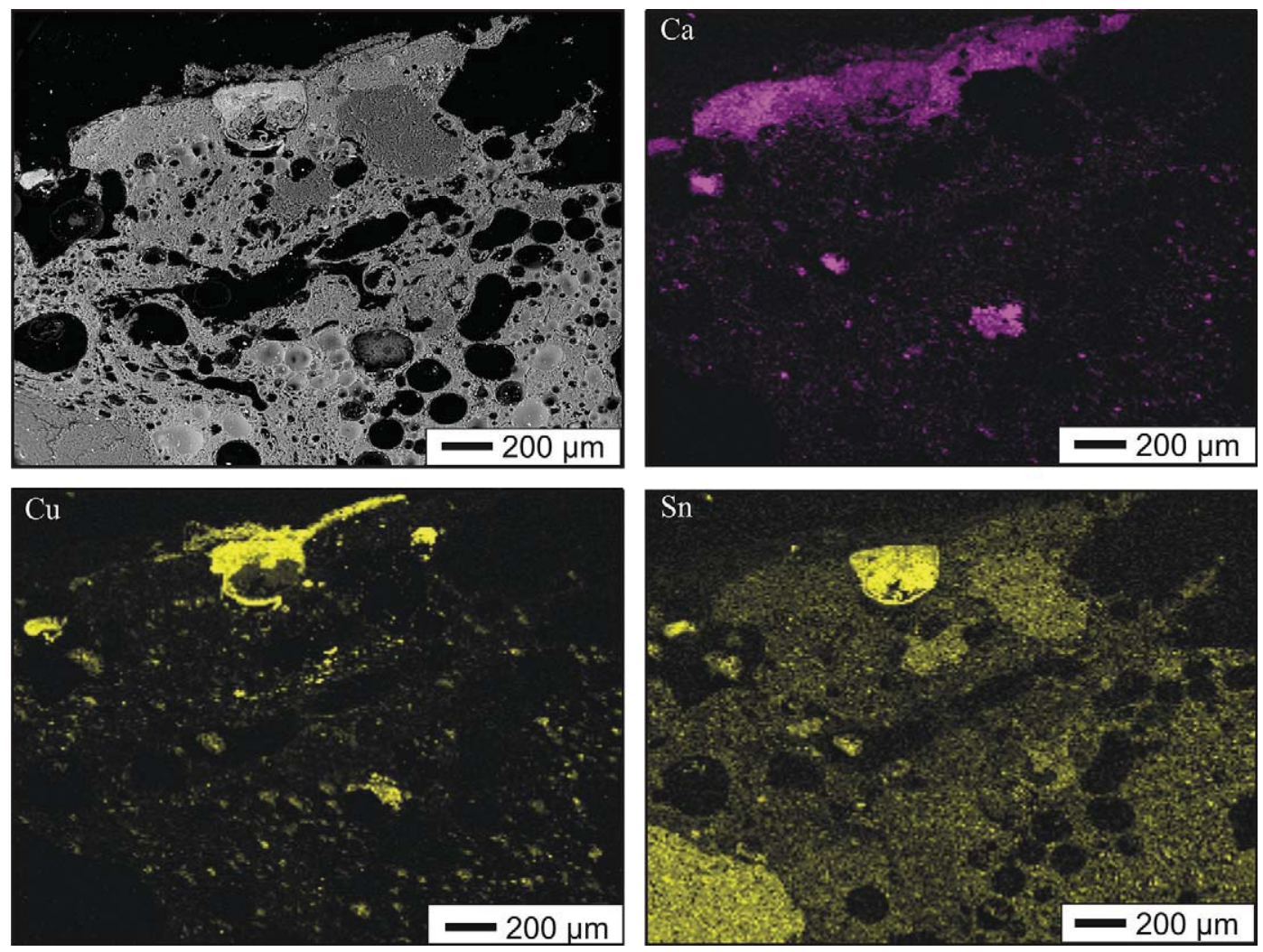

Fig. 6. SEM-BSE image and element maps showing the engobe with high calcium content compared to the inner layer; copper and tin maps showing the metal droplets within the engobe; the bright area in the left corner of the tin map corresponds to an measurement artifact (overlap of SEM-EDS Si line and Sn line).

of 50\% non-vitrified matrix (mainly mullite), and 50\% temper grains, which are composed of even amounts of quartz and feldspar, which are often intergrown (Fig. 5). In contrast, the outer layer is made up of $40 \%$ vitrified matrix containing mullite and analcime, and $60-70 \%$ temper grains consisting of more feldspar than quartz. Thus, the ceramics are predominantly composed of granite-related temper grains hosting in an orthorhombic mullite-bearing matrix which was formed by the dehydroxylation of kaolinite as well as the stepwise phase transformation to mullite, primarily initiated by the firing process. The outer layer has a slightly different chemical composition related to a marly limestone, marl or ash additive. A more detailed specification of the calcium additive was not yet possible due to missing sediment grains or locally enriched phosphate traces. However, anyone of these additives would have been

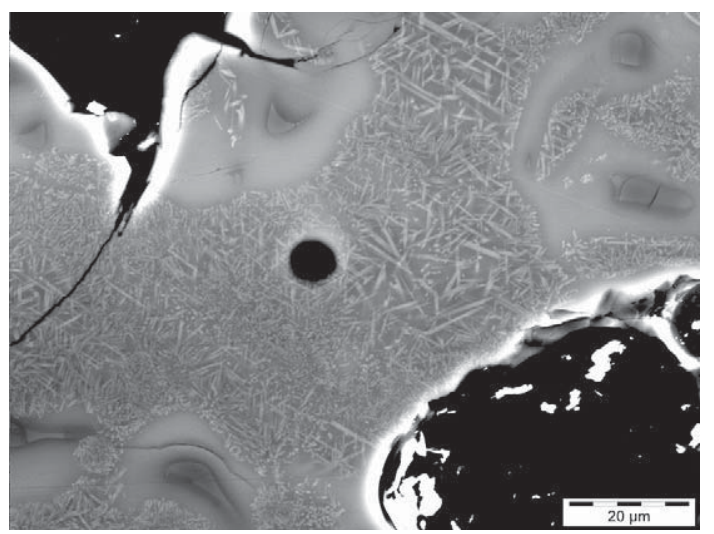

Fig. 7. SE image of acicular secondary mullite surrounded by a matrix of primary mullite. used to increase the calcium and magnesium content in order to obtain a glassy layer. A primary calcium enriched kaolinitic clay can be excluded, cause of a general rareness of such clays in nature. The use of two different kaolinitic clays implies detailed knowledge of the chemical composition of different clay types, which can be excluded for Roman times. In general, the complete mineral composition of the investigated crucibles allows conclusions about firing and collapse temperatures, which will be discussed in Section 4.4.

An outer layer resulting from a reaction with fuel ash components can be excluded, because of a missing reaction rim. Calcium and magnesium are evenly distributed in the outer layer, i.e. there exist no detectable diffusion front. Furthermore, the measured magnesium content is too low for a mid-European fuel ash mainly produced from hardwood with quite higher magnesium contents. In addition, there is a sharp boarder between both layers resulting from chemical and compositional differences (Fig. 3). Moreover, the binary plots in Fig. 9 reflecting the clay composition point towards two different clay sources.

\subsection{The engobe as a kind of inner protecting layer}

The engobe is preserved in the majority of the investigated fragments and has an average thickness of $100 \mu \mathrm{m}$ (Table 1; Fig. 10). Almost all preserved metal droplets of the investigated crucibles are distributed on top of remnants of this protecting layer and not within the semi-open porosity of the inner layer except of crack related porosity.

Besides SEM-EDS and EMPA, the engobe was analysed by Raman spectroscopy to gather additional data. XRD and XRF-WDS analysis were not performed owing to low sample amounts. However, Raman data yield no evidence for a charcoal based layer or fuel ash 
Table 2

Semi-quantitative bulk chemical data of the crucibles separated after layer (XRF-WDS); shaded - main metallic charge material.

\begin{tabular}{|c|c|c|c|c|c|c|c|c|c|c|c|c|c|c|c|c|c|c|c|c|}
\hline Sample & & $\begin{array}{l}\mathrm{SiO}_{2} \\
\text { (wt.\%) }\end{array}$ & $\begin{array}{l}\mathrm{TiO}_{2} \\
\text { (wt.\%) }\end{array}$ & $\begin{array}{l}\mathrm{Al}_{2} \mathrm{O}_{3} \\
\text { (wt.\%) }\end{array}$ & $\begin{array}{l}\mathrm{Fe}_{2} \mathrm{O}_{3 \text { tot }} \\
\text { (wt.\%) }\end{array}$ & $\begin{array}{l}\mathrm{MnO} \\
\text { (wt.\%) }\end{array}$ & $\begin{array}{l}\mathrm{MgO} \\
\text { (wt.\%) }\end{array}$ & $\begin{array}{l}\mathrm{CaO} \\
\text { (wt.\%) }\end{array}$ & $\begin{array}{l}\mathrm{Na}_{2} \mathrm{O} \\
\text { (wt.\%) }\end{array}$ & $\begin{array}{l}\mathrm{K}_{2} \mathrm{O} \\
\text { (wt.\%) }\end{array}$ & $\begin{array}{l}\mathrm{P}_{2} \mathrm{O}_{5} \\
\text { (wt.\%) }\end{array}$ & $\begin{array}{l}\text { Sum norm. } \\
\text { (wt.\%) }\end{array}$ & $\begin{array}{l}\text { Sum before } \\
\text { norm. (wt.\%) }\end{array}$ & $\begin{array}{l}\mathrm{Ba} \\
(\mathrm{ppm})\end{array}$ & $\begin{array}{l}\mathrm{Cr} \\
(\mathrm{ppm})\end{array}$ & $\begin{array}{l}\mathrm{Cu} \\
(\mathrm{ppm})\end{array}$ & $\begin{array}{l}\mathrm{Pb} \\
(\mathrm{ppm})\end{array}$ & $\begin{array}{l}\text { Sn } \\
(\mathrm{ppm})\end{array}$ & $\begin{array}{l}\mathrm{Sr} \\
(\mathrm{ppm})\end{array}$ & $\begin{array}{l}\mathrm{Zn} \\
(\mathrm{ppm})\end{array}$ \\
\hline \multirow[t]{2}{*}{ ATM 001} & In & 68.5 & 0.7 & 23.9 & 1.8 & 0.02 & 0.6 & 0.5 & 0.4 & 3.5 & 0.3 & 100 & 99.1 & 1000 & 38 & 1320 & 29 & 230 & $<100$ & 3960 \\
\hline & Out & 69.2 & 0.7 & 15.3 & 3.1 & 0.07 & 0.8 & 4.3 & 1.2 & 4.8 & 0.7 & 100 & 94.1 & 1390 & 75 & 768 & 32 & 16 & 118 & 1010 \\
\hline \multirow[t]{2}{*}{ ATM 002} & In & 72.8 & 0.6 & 20.8 & 1.3 & 0.02 & 0.4 & 0.3 & 0.3 & 3.2 & 0.2 & 100 & 93.5 & 1410 & 31 & 259 & 46 & 22 & $<100$ & 3580 \\
\hline & Out & 67.6 & 0.6 & 19.0 & 1.7 & 0.13 & 0.9 & 4.8 & 0.4 & 4.5 & 0.3 & 100 & 94.7 & 3140 & 42 & 810 & 54 & 9 & 205 & 1540 \\
\hline \multirow{2}{*}{ ATM 003} & In & 72.2 & 0.7 & 20.3 & 2.0 & 0.04 & 0.4 & 0.3 & 0.4 & 3.2 & 0.3 & 100 & 94.3 & 1110 & 31 & 451 & 50 & 46 & $<100$ & 25,500 \\
\hline & Out & 74.6 & 0.6 & 15.7 & 2.4 & 0.07 & 0.7 & 1.0 & 0.8 & 4.0 & 0.3 & 100 & 96.3 & 1400 & 48 & 969 & 30 & 43 & 105 & 2650 \\
\hline \multirow{3}{*}{$\underbrace{}_{\text {ATM }} 004$} & In & 68.6 & 0.7 & 23.6 & 1.6 & 0.02 & 0.5 & 0.4 & 0.4 & 3.8 & 0.3 & 100 & 91.2 & 1340 & 50 & 520 & 86 & 51 & 113 & 28,700 \\
\hline & Out & 73.2 & 0.6 & 15.4 & 3.2 & 0.05 & 0.9 & 0.7 & 1.0 & 4.9 & 0.3 & 100 & 96.0 & 1930 & 42 & 196 & 54 & - & 124 & 1760 \\
\hline & In & 73.2 & 0.6 & 20.1 & 1.5 & 0.02 & 0.5 & 0.3 & 0.4 & 3.2 & 0.2 & 100 & 91.4 & 1300 & 25 & 397 & 78 & 20 & $<100$ & 15,200 \\
\hline \multirow{2}{*}{ स्थM 006} & Out & 72.1 & 0.6 & 17.7 & 3.4 & 0.03 & 0.6 & 0.6 & 0.5 & 4.2 & 0.3 & 100 & 89.5 & 958 & 39 & 1060 & 95 & 65 & $<100$ & 11,600 \\
\hline & In & 69.9 & 0.6 & 20.6 & 1.9 & 0.05 & 0.6 & 1.1 & 0.5 & 4.6 & 0.3 & 100 & 90.2 & 2080 & 25 & 405 & 91 & 12 & 105 & 12,900 \\
\hline \multirow{4}{*}{ 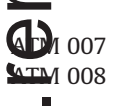 } & Out & 67.2 & 0.3 & 17.2 & 1.9 & 0.16 & 0.8 & 5.7 & 0.6 & 5.4 & 0.7 & 100 & 92.7 & 1790 & 29 & 2330 & 71 & 49 & 166 & 4400 \\
\hline & Bulk & 71.5 & 0.4 & 18.4 & 1.3 & 0.03 & 0.5 & 2.2 & 0.7 & 4.4 & 0.6 & 100 & 91.4 & 1300 & 24 & 9210 & 118 & 393 & 102 & 8510 \\
\hline & In & 69.2 & 0.7 & 24.2 & 1.6 & 0.01 & 0.5 & 0.2 & 0.3 & 3.2 & 0.2 & 100 & 93.1 & 1470 & 33 & 238 & 18 & 17 & $<100$ & 337 \\
\hline & Out & 67.9 & 0.6 & 20.0 & 3.0 & 0.06 & 0.9 & 1.7 & 0.7 & 5.0 & 0.3 & 100 & 90.2 & 1670 & 64 & 195 & 45 & - & 124 & 460 \\
\hline \multirow{2}{*}{ (AT) 009} & In & 64.5 & 0.8 & 28.5 & 1.7 & 0.01 & 0.6 & 0.2 & 0.3 & 3.2 & 0.2 & 100 & 99.4 & 1070 & 49 & 150 & 27 & 8 & $<100$ & 6900 \\
\hline & Out & 71.4 & 0.7 & 16.8 & 3.0 & 0.05 & 0.8 & 1.7 & 1.0 & 4.5 & 0.2 & 100 & 93.5 & 1020 & 55 & 391 & 70 & 20 & 115 & 1060 \\
\hline \multirow{3}{*}{$\underbrace{T M} 010$} & In & 67.8 & 0.7 & 24.6 & 2.0 & 0.03 & 0.5 & 0.3 & 0.3 & 3.4 & 0.3 & 100 & 92.4 & 934 & 28 & 4150 & 62 & 74 & $<100$ & 7370 \\
\hline & Out & 65.7 & 0.6 & 15.6 & 4.1 & 0.46 & 0.5 & 3.0 & 2.7 & 5.1 & 2.3 & 100 & 91.6 & 2810 & 34 & 1520 & 45 & 69 & 245 & 929 \\
\hline & In & 68.6 & 0.7 & 23.6 & 1.8 & 0.03 & 0.6 & 0.3 & 0.4 & 3.7 & 0.3 & 100 & 97.9 & 1070 & 40 & 986 & 100 & 204 & 112 & 1000 \\
\hline \multirow{3}{*}{$\begin{array}{l}\text { ATM } 012 \\
\text { ATPL_013 }\end{array}$} & Out & 74.7 & 0.6 & 10.3 & 2.7 & 0.39 & 0.7 & 4.0 & 0.8 & 5.1 & 0.8 & 100 & 91.4 & 3800 & 24 & 1830 & 42 & 7 & 205 & 445 \\
\hline & Bulk & 71.6 & 0.6 & 19.0 & 1.7 & 0.06 & 0.6 & 1.6 & 0.7 & 3.9 & 0.3 & 100 & 89.5 & 1800 & 30 & 877 & 69 & 44 & 121 & 8170 \\
\hline & In & 70.4 & 0.6 & 19.9 & 2.0 & 0.06 & 0.7 & 1.1 & 0.5 & 4.5 & 0.3 & 100 & 91.8 & 2040 & 73 & 453 & 64 & 5 & 107 & 7670 \\
\hline \multirow{3}{*}{014} & Out & 69.6 & 0.3 & 17.9 & 1.8 & 0.11 & 0.7 & 3.1 & 0.8 & 5.3 & 0.3 & 100 & 96.0 & 1640 & 29 & 5040 & 88 & 165 & 130 & 4620 \\
\hline & In & 68.1 & 0.8 & 23.4 & 2.0 & 0.02 & 0.6 & 0.4 & 0.5 & 4.1 & 0.2 & 100 & 90.4 & 1160 & 55 & 681 & 59 & 54 & 116 & 10900 \\
\hline & Out & 69.5 & 0.6 & 13.3 & 3.9 & 0.45 & 0.7 & 3.8 & 0.9 & 6.3 & 0.5 & 100 & 94.6 & 1870 & 79 & 1810 & 34 & 49 & 152 & 474 \\
\hline \multirow{4}{*}{$\begin{array}{l}\text { ATM } 015 \\
\text { ATM } 016 \\
\text { ATM } 017\end{array}$} & Bulk & 72.5 & 0.6 & 19.2 & 1.8 & 0.03 & 0.7 & 0.5 & 0.5 & 3.9 & 0.3 & 100 & 88.8 & 1350 & 29 & 138 & 81 & 37 & $<100$ & 7980 \\
\hline & Bulk & 66.9 & 0.8 & 23.4 & 2.1 & 0.02 & 0.6 & 1.4 & 0.4 & 4.1 & 0.3 & 100 & 89.6 & 1190 & 56 & 770 & 50 & 100 & 131 & 18,300 \\
\hline & In & 71.3 & 0.8 & 20.4 & 2.1 & 0.04 & 0.5 & 0.5 & 0.5 & 3.6 & 0.3 & 100 & 91.4 & 1130 & 49 & 204 & 60 & 16 & 107 & 12,400 \\
\hline & Out & 69.4 & 0.4 & 17.5 & 1.8 & 0.25 & 0.8 & 4.4 & 0.6 & 4.6 & 0.4 & 100 & 93.5 & 1710 & 18 & 328 & 50 & 27 & 214 & 3180 \\
\hline \multirow{2}{*}{ ATM 018} & In & 71.1 & 0.6 & 19.8 & 1.8 & 0.05 & 0.6 & 1.1 & 0.4 & 4.2 & 0.3 & 100 & 92.8 & 2190 & 36 & 304 & 47 & - & 103 & 7350 \\
\hline & Out & 72.6 & 0.8 & 12.9 & 2.5 & 0.14 & 0.8 & 3.5 & 0.7 & 5.7 & 0.4 & 100 & 91.0 & 1520 & 58 & 713 & 37 & - & 171 & 570 \\
\hline
\end{tabular}



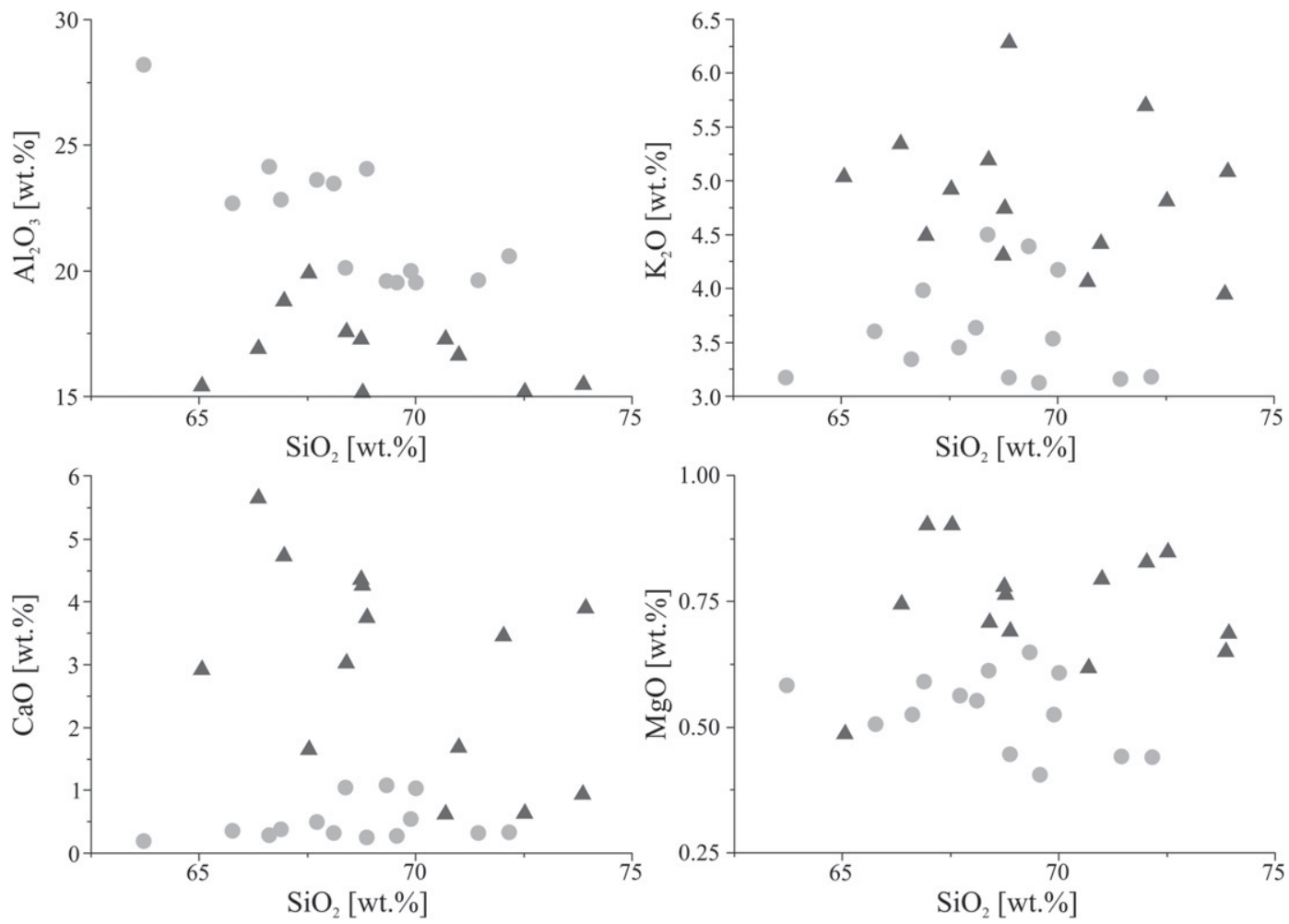

Fig. 8. Diagrams of selected XRF data points allowing a distinct separation related to $\mathrm{Al}_{2} \mathrm{O}_{3}, \mathrm{MgO}, \mathrm{CaO}$ and $\mathrm{K}_{2} \mathrm{O}$ in the main layers (inner layer - dots; outer layer - triangles).
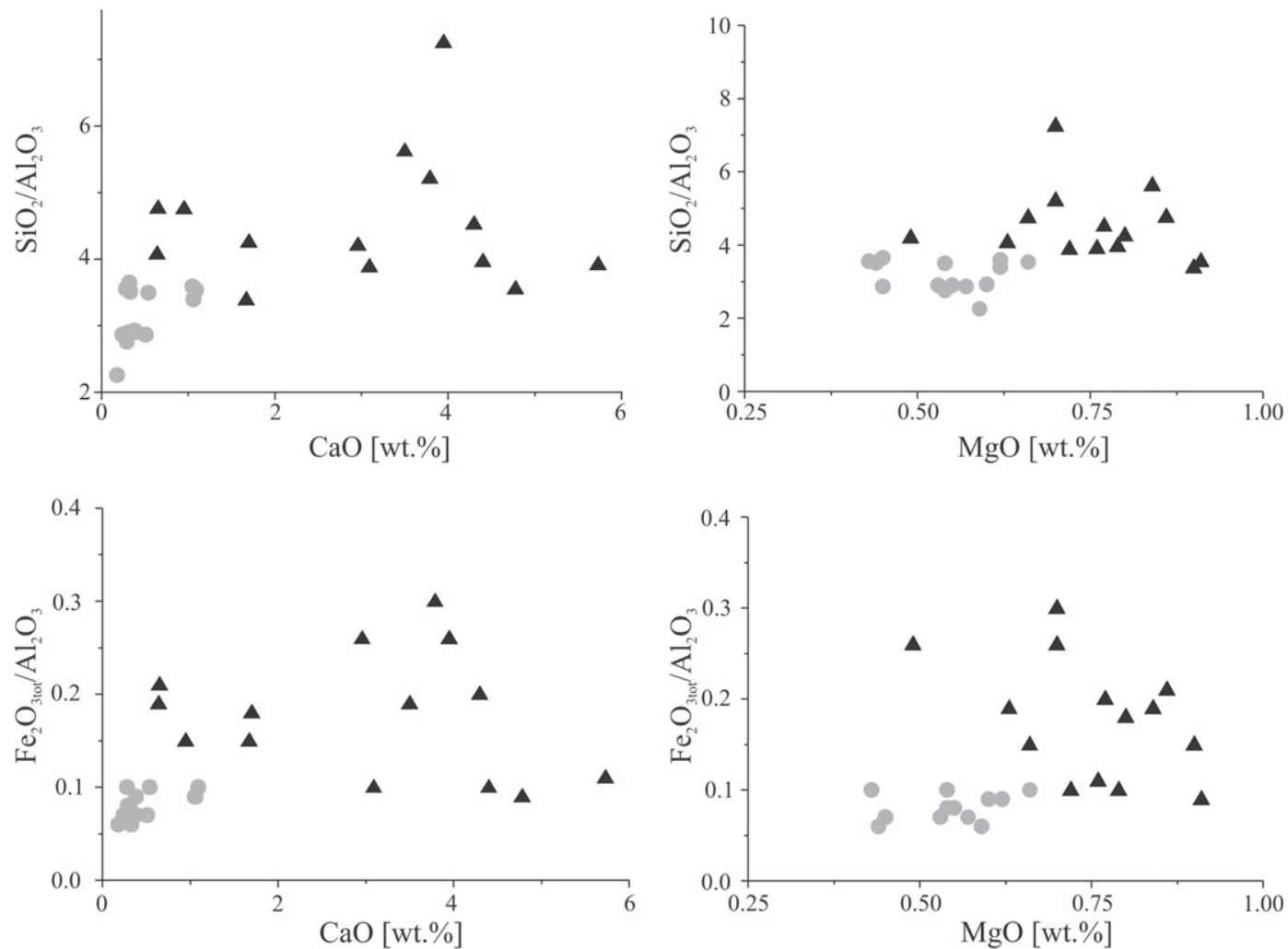

Fig. 9. Binary diagrams of $\mathrm{SiO}_{2} / \mathrm{Al}_{2} \mathrm{O}_{3}$ and $\mathrm{Fe}_{2} \mathrm{O}_{3}$ tot $/ \mathrm{Al}_{2} \mathrm{O}_{3}$ ratios plotted against $\mathrm{CaO}$ and $\mathrm{MgO}$ indicating no linear dependence between the inner and the outer layer (inner layer dots; outer layer - triangles). 


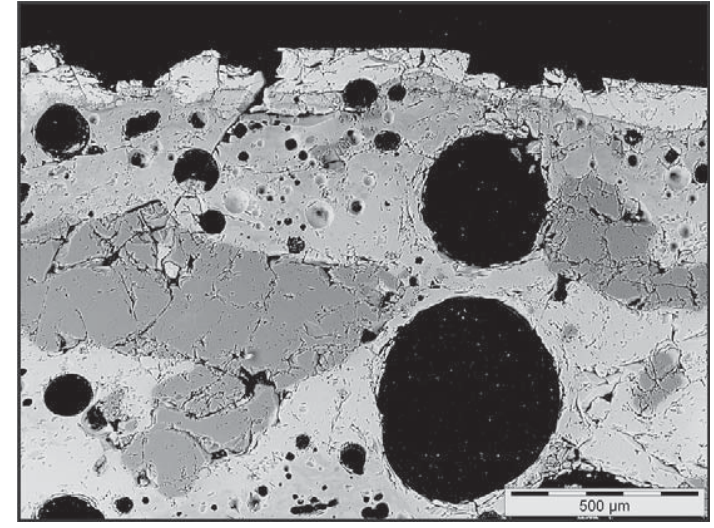

Fig. 10. BSE image of the vitrified engobe and the ceramic inner layer of the crucible ATM 002.

migration within the inner layer. Both, SEM-EDS and EMPA (Table 3) deliver enriched amounts of calcium, potassium and silicon with respect to the inner layer. In general, the results indicate a similar composition like the outer layer except of temper grains, which are missing in the engobe. The instability under the electron beam also indicates a predominantly vitrified character of this layer. Generally, these results favour a similar raw material like the matrix material of the outer layer. Therefore we assume that this engobe is neither the result of migration processes nor formed during use. This layer is rather an added layer with protecting function than a layer formed by chance. One important indication for this theory is the consistent existents of this engobe from the bottom to the top of the crucibles with almost the same composition in several investigated fragments.

\subsection{Multiple usages}

An indicator for multiple usages is given by the ceramic material itself. Clearly visible repair marks on the outer layer are present in some of the investigated crucible sherds. These are characterised by a duplication of the outer layer, which is marked by the multiplication of the reddish coloured surfaces. The internal composition, structure and main element chemistry of these both layers is almost identical. Thus, we assume an identical raw material used for the primary outer layer and the added one. The overall implication is that the crucible itself was used at least two times.

Preliminary microprobe analyses on preserved metal particles give a hint for multiple usages, too. In general, there are two kinds of alloys found in single crucibles, $\mathrm{Cu}-\mathrm{Zn}$ and $\mathrm{Cu}-\mathrm{Sn}$, with minor traces of iron and lead (unpublished results).

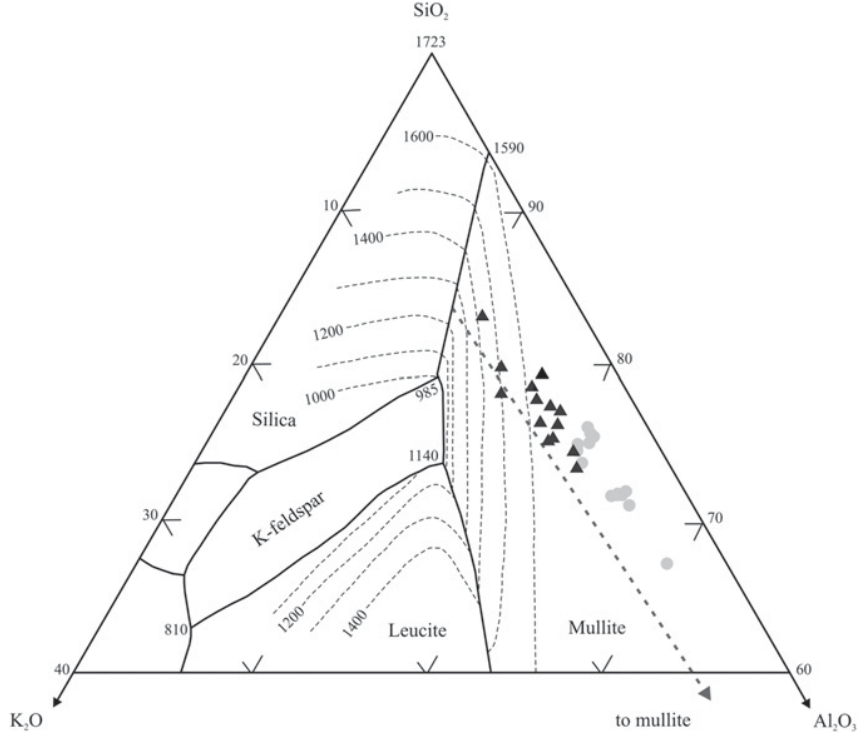

Fig. 11. High-silica part of the $\mathrm{SiO}_{2}-\mathrm{K}_{2} \mathrm{O}-\mathrm{Al}_{2} \mathrm{O}_{3}$ phase diagram (modified after Osborn, 1977; Maggetti et al., 2010). Isotherms are shown every hundred degrees; temperatures in ${ }^{\circ} \mathrm{C}$. The fat dotted line is the projection toward the mullite-silica cotectic line. The grey dots correspond to the inner layer and the black triangles to the outer layer.

\subsection{Estimation of firing temperatures}

For the discrimination of a certain firing temperature interval, a combination of different methods had to be used. XRD analyses which represent the coexistence of various mineral phases serve as an indicator for reached temperature ranges. According to Lee et al. (1999), elongated mullite needles develop between 1100 and $1200{ }^{\circ} \mathrm{C}$ and diminish the amount of previously formed spinel. The crystallisation of cristobalite from an amorphous silicate-rich phase starts at temperatures above $1300{ }^{\circ} \mathrm{C}$. This minimum temperature can also favour the coexistence of orthorhombic mullite $\left(\mathrm{Al}_{6} \mathrm{Si}_{2} \mathrm{O}_{13}\right)$ and cristobalite (Gualtieri et al., 1995; Lee et al., 1999).

The sum of $\mathrm{SiO}_{2}, \mathrm{Al}_{2} \mathrm{O}_{3}$ and $\mathrm{K}_{2} \mathrm{O}$ yields between 90 and $96 \%$, which allows us to use the ternary $\mathrm{SiO}_{2}-\mathrm{K}_{2} \mathrm{O}-\mathrm{Al}_{2} \mathrm{O}_{3}$ phase diagram to estimate the maximum stability temperatures of the investigated ceramics. The residual $4-10 \%$ are mainly attributed to $\mathrm{CaO}$ containing additives, which were used to lower the breakdown temperature of the outer layer. In general, the inner layer is characterised by a significant higher amount of $\mathrm{Al}_{2} \mathrm{O}_{3}$ compared to the outer layer, which corresponds to a higher amount of kaolinitic clay and therefore a high amount of mullite in the ceramic (Fig. 11).

Table 3

EMPA data of the engobe of three different crucibles.

\begin{tabular}{|c|c|c|c|c|c|c|c|c|c|c|c|c|c|c|}
\hline Sample & $\begin{array}{l}\mathrm{SiO}_{2} \\
\text { (wt.\%) }\end{array}$ & $\begin{array}{l}\mathrm{TiO}_{2} \\
\text { (wt.\%) }\end{array}$ & $\begin{array}{l}\mathrm{Al}_{2} \mathrm{O}_{3} \\
\text { (wt.\%) }\end{array}$ & $\begin{array}{l}\mathrm{Fe}_{2} \mathrm{O}_{3 \text { tot }} \\
\text { (wt.\%) }\end{array}$ & $\begin{array}{l}\mathrm{MnO} \\
\text { (wt.\%) }\end{array}$ & $\begin{array}{l}\mathrm{MgO} \\
\text { (wt.\%) }\end{array}$ & $\begin{array}{l}\mathrm{CaO} \\
\text { (wt.\%) }\end{array}$ & $\begin{array}{l}\mathrm{Na}_{2} \mathrm{O} \\
\text { (wt.\%) }\end{array}$ & $\begin{array}{l}\mathrm{K}_{2} \mathrm{O} \\
\text { (wt.\%) }\end{array}$ & $\begin{array}{l}\mathrm{P}_{2} \mathrm{O}_{5} \\
\text { (wt.\%) }\end{array}$ & $\begin{array}{l}\mathrm{CuO}_{\text {tot }} \\
\text { (wt.\%) }\end{array}$ & $\begin{array}{l}\mathrm{SnO}_{\text {tot }} \\
\text { (wt.\%) }\end{array}$ & $\begin{array}{l}\mathrm{ZnO} \\
\text { (wt.\%) }\end{array}$ & Total \\
\hline ATM 002 & 52.78 & 0.77 & 23.40 & 1.87 & 0.23 & 0.95 & 7.81 & 1.16 & 8.04 & 0.16 & - & 0.02 & 3.76 & 100.94 \\
\hline ATM 002 & 53.15 & 0.72 & 22.51 & 1.73 & 0.32 & 0.99 & 8.19 & 1.07 & 8.51 & 0.45 & - & 0.02 & 3.31 & 100.98 \\
\hline ATM 002 & 54.58 & 0.69 & 22.09 & 1.26 & 0.32 & 0.96 & 8.03 & 1.12 & 9.04 & - & 0.08 & - & 2.44 & 100.61 \\
\hline ATM 002 & 52.68 & 0.74 & 23.27 & 1.71 & 0.32 & 0.94 & 8.51 & 1.11 & 8.43 & 0.44 & - & - & 2.79 & 100.94 \\
\hline ATM 002 & 53.80 & 0.57 & 20.84 & 2.76 & 0.22 & 1.21 & 7.19 & 1.06 & 8.04 & 0.74 & - & - & 3.63 & 100.05 \\
\hline ATM 002 & 55.40 & 0.54 & 19.68 & 2.82 & 0.27 & 1.25 & 6.77 & 1.07 & 8.23 & 0.54 & - & - & 4.11 & 100.68 \\
\hline ATM 002 & 55.94 & 0.45 & 16.33 & 1.93 & 0.28 & 1.12 & 11.52 & 0.90 & 5.95 & 0.74 & - & 0.01 & 5.04 & 100.19 \\
\hline ATM 004 & 48.12 & 0.17 & 31.92 & 0.52 & 0.03 & 0.17 & 15.22 & 1.36 & 1.22 & 0.40 & 0.54 & 0.03 & 1.18 & 100.87 \\
\hline ATM 004 & 45.55 & 0.43 & 34.19 & 1.29 & 0.08 & 0.81 & 1.00 & 1.98 & 5.94 & 0.18 & - & 0.02 & 9.15 & 100.62 \\
\hline ATM 004 & 48.90 & 0.77 & 11.86 & 3.35 & 0.83 & 2.17 & 16.94 & 1.27 & 3.30 & - & 0.20 & 0.04 & 10.59 & 100.22 \\
\hline ATM 012 & 57.11 & 0.61 & 16.43 & 0.63 & 0.45 & 2.02 & 15.24 & 2.12 & 4.68 & - & 0.01 & - & 1.02 & 100.33 \\
\hline ATM 012 & 54.39 & 0.65 & 15.34 & 0.38 & 0.54 & 2.30 & 20.91 & 1.00 & 3.36 & 0.28 & 0.72 & - & 0.60 & 100.48 \\
\hline ATM 012 & 55.42 & 0.60 & 16.22 & 0.19 & 0.53 & 2.28 & 20.31 & 1.04 & 3.39 & 0.13 & 0.32 & - & 0.25 & 100.68 \\
\hline ATM 012 & 57.34 & 0.77 & 17.85 & 0.71 & 0.39 & 1.80 & 12.61 & 2.08 & 5.51 & 0.43 & 0.20 & 0.01 & 1.01 & 100.72 \\
\hline
\end{tabular}




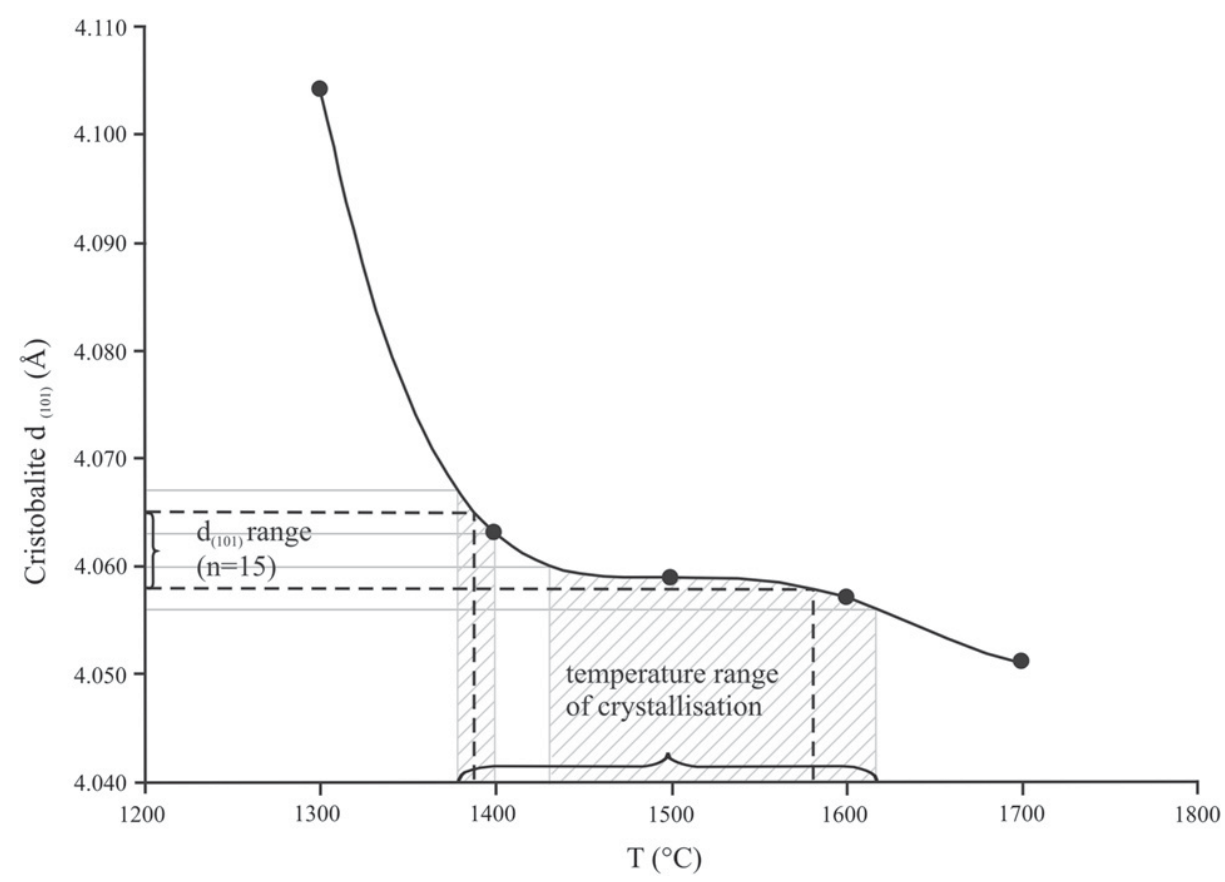

Fig. 12. Variation curve of the cristobalite $d_{(101)}$ peak as a function of temperature (after Eramo, 2005). The dotted lines show the $d_{(101)}$ range of the crucibles in 15 samples as well as the corresponding range of formation temperature. The grey shaded area displays the error of the peak position.

Cristobalite and tridymite are high temperature - low pressure silica polymorphs. It is generally accepted that pure silica systems do not generate tridymite as a stable phase (Hill and Roy, 1958; Holmquist, 1961; Stevens et al., 1997). The $\mathrm{SiO}_{2}$ transformation is thus not only a function of pressure and temperature, but composition. Stevens et al. (1997) argued that sodium or potassium carbonate additives can favour the formation of tridymite in $\mathrm{SiO}_{2}$ rich ceramics. However, despite traces of potassium and sodium, tridymite is missing in all samples. Recent works of Artioli et al. (2008) and Pradell et al. (2010) have demonstrated that tridymite formation is related to the existence of stabilising alkali ions, but, the differences in the reached temperatures and pressures are in fact also important. The phase transition of $\alpha$-quartz to $\beta$-cristobalite in pure silica systems occurs above temperatures of $1400{ }^{\circ} \mathrm{C}$ with an intermediate amorphous phase (Stevens et al., 1997). Multielement/-mineral ceramics as presented here tend to influence such reaction temperatures and probably resulting in lower temperatures of such phase transitions. Due to the fact that the crystalline order of cristobalite is increasing with temperature (Eramo, 2005; Sosman, 1965; Verduch, 1958), it is possible to use the $d_{(101)}$ peak range as a temperature indicator, which shifts to lower $d$ values as the formation temperatures increase (Eramo, 2005; Verduch, 1958). The $d_{(101)}$ cristobalite peak positions of 15 crucibles (Fig. 12) lie in the range of $0.4058-0.4065 \mathrm{~nm}( \pm 0.0002 \mathrm{~nm})$, which correspond to firing temperatures above $1380^{\circ} \mathrm{C}$.

In addition, the amount of analcime, which is a secondary devitrification product of potassium- and sodium-rich glassy phases under humid and acidic environmental conditions in the burial stage, can be used as indicator for firing temperatures higher than $1200{ }^{\circ} \mathrm{C}$. In general, the amount of analcime increases with increasing firing temperature (Buxeda et al., 2002; Pradell et al., 2010; Schwedt et al., 2006).

All these data indicate firing temperatures higher than necessary for the production of $\alpha$-brass with melting point of around $1000-1050{ }^{\circ} \mathrm{C}$. Nevertheless, the mineral assemblage indicates firing temperatures between 1200 and $1400{ }^{\circ} \mathrm{C}$, i.e. much higher than the necessary melting temperature. Such an overheating might be necessary to melt the load in large crucibles as shown in Fig. 2 in a moderate period of time. Moreover, it enables a longer handling of the molten content to produce a higher number of small artefacts like fibulae. Indications for such a high overheating are present in all investigated crucible fragments. This fact demonstrates the skills of Roman craftsmen which enabled them to produce in an "industrial" way, i.e. consistent production of a high quantity of crucibles and metal artefacts during decades.

\section{Conclusion}

Summing up, the results of this work demonstrate that all investigated crucibles are double-layered with clear mineralogical and structural differences in individual layers. Owing to differences in the feldspar-quartz proportions of the temper grains, it is possible to propose a granitic source for the raw material. The matrix of both layers consists of kaolinitic clay with high refractory characteristics. Only the outer layer has an additive which reduces the refractory performance of the matrix material, thus increasing the insulation function of the layer. The detected engobe consists of a material nearly identical to the matrix of the outer layer. It delays the migration of a liquid metal charge, giving it a protecting function and avoiding metal losses.

Clear evidence for a multiple usage were presented based on partial duplication of the outer layer as well as varying metal compositions of the metal droplets in single crucibles. The applied cristobalite peak method and temperature estimation derived from the mineral assemblage suggest relatively high firing temperatures $\left(\geq 1380{ }^{\circ} \mathrm{C}\right)$. This range is generally higher than temperatures described for Roman metal-melting crucibles in literature (Freestone, 1989; Hein et al., 2007; Rehren, 2003; Tylecote, 1982). However, such high pre-firing temperatures are already reported from a 15th/16th century excavation in Hesse/Germany (MartinónTorres et al., 2008) and from the 17th century glass-melting crucibles from Derrière Sairoche/Switzerland (Eramo, 2006).

Overall, the crucibles were produced using a certain routine, which seems to be identical for all analysed fragments. At first the 
inner layer was built up of kaolinitic clay and a granite-related temper. This layer has been dried or fired at low temperatures. Afterwards, the outer layer consisting of a different kind of clay with a higher calcium content and granitic temper was added. The engobe was probably produced simultaneously by elutriate the clay of the outer layer and dispersing this suspension along the inner layer of the crucible which initially led to a millimetre thin layer covering the whole inside. Subsequent firing created a glassy engobe and outer layer with a ceramic inner layer in-between. Thus, the used production routine seems to be an appropriate method to produce crucibles stable under high temperature and suited for a multiple use.

\section{Acknowledgements}

This paper is part of a PhD thesis under the supervision of Prof. Vincent Serneels (University of Fribourg). Special thanks go to Prof. Bernard Grobéty and Prof. Marino Maggetti (both University of Fribourg) for their helpful suggestions and discussions. I thank Mr. Christoph Neururer (University of Fribourg) for his technical support, Dr. Martin Robyr (University of Bern) for the EMPA support and Dr. Eric Reusser (ETH Zurich) for the Raman support. The author also expresses gratitude to the anonymous referees for the careful reviews.

\section{References}

Artioli, G., Angelini, I., Polla, A., 2008. Crystals and phase transitions in protohistoric glass materials. Phase Transitions 81, 233-252.

Bayley, J., 1992. Metalworking ceramics. Medieval Ceramics 16, 3-10.

Bayley, J., Rehren, Th, 2007. Towards a functional and typological classification of crucibles. In: La Niece, S., Hook, D., Craddock, P.T. (Eds.), Metals and Mines Studies in Archaeometallurgy. Archetype, London, pp. 46-55.

Buxeda, J., Mommsen, H., Tsolakidou, A., 2002. Alterations of $\mathrm{Na}, \mathrm{K}$ and $\mathrm{Rb}$ concentrations in Mycenaean pottery and a proposed explanation using X-ray diffraction. Archaeometry 44, 187-198.

Chardron-Picault, P., Pernot, M., 1999. Un quartier antique d'artisanat métallurgique à Autun- Le site du Lycée militaire. Editions de la Maison des sciences de l'homme. Documents d'Archéologie Française 76, Paris.

Eramo, G., 2005. The melting furnace of the Derrière Sairoche glassworks (Court, Swiss Jura): heat-induced mineralogical transformations and their technological signification. Archaeometry 47, 571-592.

Eramo, G., 2006. The glass-melting crucibles of Derrière Sairoche (1699-1714 AD, Ct. Bern, Switzerland): a petrological approach. Journal of Archaeological Science 33, 440-452.

Freestone, I.C., 1989. Refractory materials and their procurement. In: Hauptmann, A., Pernicka, E., Wagner, G. (Eds.), Old World Archaeometallurgy. Der Anschnitt, Beiheft 7. Deutsches Bergbau-Museum, Bochum, pp. 155-162.
Gualtieri, A., Bellotto, M., Artioli, G., Clark, S.M., 1995. Kinetic study of the kaolinitemullite reaction sequence. Part II: mullite formation. Physics and Chemistry of Minerals 22, 215-222.

Hein, A., Kilikoglou, V., Kassianidou, V., 2007. Chemical and mineralogical examination of metallurgical ceramics from a Late Bronze Age copper smelting site in Cyprus. Journal of Archaeological Science 34, 141-154.

Hill, V.G., Roy, R., 1958. Silica structure studies, VI, on tridymite. Transactions of the British Ceramic Society 57, 496-510.

Holmquist, S.B., 1961. Conversion of quartz to tridymite. Journal of the American Ceramic Society 44, 82-86.

Lee, W.E., Iqbal, Y., 2001. Influence of mixing on mullite formation in porcelain. Journal of the European Ceramic Society 21, 2583-2586.

Lee, S., Kim, Y.J., Moon, H., 1999. Phase transformation sequence from kaolinite to mullite investigated by energy-filtering transmission electron microscope. Journal of the American Ceramic Society 43, 2841-2848.

Maggetti, M., Kahr, G., 1980. Homogenität archäologischer keramischer Objekte: Teil I. Porosität und Porenradienverteilung. Archäologie und Naturwissenschaften $2,1-20$.

Maggetti, M., Rosen, J., Neururer, C., Serneels, V., 2010. Paul-Louis Cyfflé's (1724-1806) Terre de Lorraine: a technological study. Archaeometry 52, 707-732.

Martinón-Torres, M., Freestone, I., Hunt, A., Rehren, Th, 2008. Mass-produced mullite crucibles in medieval Europe: manufacture and material properties. Journal of the American Ceramic Society 91, 2071-2074.

Modarressi-Tehrani, D., 2004. Ein Ensemble frühlatènezeitlicher Metallverarbeitung aus der Siedlung von Eberdingen-Hochdorf (Lkr. Ludwigsburg). Metalla 11.1, Bochum.

May, J.O., Butterworth, B., 1962. Studies of pore size distribution III. The effect of firing temperatures. Science of Ceramics 1, 201-221.

Nielen, H.-D., 2006. Zink oder Messing? Ein Beitrag zu den metallurgischen Tätigkeiten im Legionslager Neuss. Metalla 13.1, Bochum.

Osborn, E.F., 1977. Phase-diagrams and refractories. American Ceramic Society Bulletin 56, 654-659.

Pradell, T., Molera, J., Salvado, N., Labrador, A., 2010. Synchrotron radiation microXRD in the study of glaze technology. Applied Physics A-Materials Science \& Processing 99, 407-417.

Rehren, Th, 2003. Crucibles as reaction vessels in ancient metallurgy. In: Craddock, P.T., Lang, J. (Eds.), Mining and Metal Production Through the Ages. British Museum Press, London, pp. 207-215.

Schwedt, A., Mommsen, H., Zacharias, N., Buxeda, J., 2006. Analcime crystallization and compositional profiles - comparing approaches to detect post-depositional alterations in archaeological pottery. Archaeometry 48, 237-251.

Sosman, R.B., 1965. The Phases of Silica. Rutgers University Press, New Brunswick, New Jersey.

Stevens, S.J., Hand, R.J., Sharp, J.H., 1997. Polymorphism of silica. Journal of Material Science 32, 2929-2935.

Thornton, C.P., Rehren, Th, 2009. A truly refractory crucible from fourth millennium Tepe Hissar, Northeast Iran. Journal of Archaeological Science 36, 2700-2712.

Tite, M.S., Freestone, I.C., Meeks, N.D., Craddock, P.T., 1985. The examination of refractory ceramics from metal-production and metalworking sites. In: The Archaeologist and the Laboratory. Council for British Archaeology Research Report 58, pp. 50-55.

Tylecote, R.F., 1982. Metallurgical crucibles and crucible slags. In: Olin, J.S., Franklin, A.D. (Eds.), Archaeological Ceramics. Smithsonian Institution Press, Washington, pp. 231-243.

Verduch, A.G., 1958. Kinetics of cristobalite formation from silicic acid. Journal of the American Ceramic Society 41, 427-432. 